\title{
The Ghana-Canada Global Community Service Learning Project: Teaching and Learning through Sharing and Praxis
}

\author{
Charles Quist-Adade ${ }^{1}$
}

The Ghana-Canada Global Community Service Learning Project (GCP, for short) is a multi-layered, international, crossdisciplinary, collaborative, mixed mode teaching and learning, and praxis-oriented undertaking, which uses simple technology, internship and field research to provide opportunity for students and scholars in Ghana and Canada to learn the skills of global citizenship while engaging, inspring, supporting and empowering deprived students in rural Ghana in an environmentally-friendly and sustainable way. This paper is a brief description of the "nuts and bolts" of the project, its successes and challenges. [Article copies available for a fee from The Transformative Studies Institute. E-mail address: journal@transformativestudies.org http://www.transformativestudies.org $\quad$ (C)2013 by The Transformative Studies Institute. All rights reserved.]

KEYWORDS: Service Learning, Praxis, Transformative, Global Citizenship, Cultural Literacy, Reality Learning, Ghana Field School.

"Theory without practice is blind; practice without theory is empty."

Kwame Nkrumah

\footnotetext{
${ }^{1}$ Charles Quist-Adade, Ph.D., is Sociology professor and Co-Chair of the Sociology Department at Kwantlen Polytechnic University. His research and teaching interests are Social justice, Globalization and Development, Racialization and Ethnicity and Media and Society, and Social Theory. His other areas of teaching and research interest revolve around "Third World" issues and religion. He is the author of several books - In the Shadows of the Kremlin and the White House: Africa's Media Image from Communism to Post-Communism, and Social Justice in Local and Global Contexts, From Colonization to Globalization: The Intellectual and Political Legacies of Kwame Nkrumah (Co-editor). Address correspondence to: Charles Quist-Adade, Kwantlen Polytechnic University, 12666 72nd Avenue, Surrey, Canada V3W 2M8; e-mail: charles.quistadade@kwantlen.ca.
}

1937-0229 (C2013 Transformative Studies Institute 